\title{
MUTILASI DALAM PERSPEKTIF HUKUM PIDANA (ISLAM)
}

\author{
Oleh : \\ Amsori, SH., MH., MM. \\ Dosen Tetap pada Program Strata Satu Sekolah Tinggi Ilmu Hukum "IBLAM" \\ dan sekarang sedang mengikuti Kuliah Program Doktor Studi Pengkajian Islam pada Sekolah Pascasarjana \\ Universitas Islam Negeri Syarif Hidayatullah Jakarta \\ Email : (amsori.sh@gmail.com)
}

\begin{abstract}
:
Crime is a problem faced by humans from time to time. Talking about crime, especially murder, continues to experience growth accompanied by style and shape are very diverse, from the most simple to very sophisticated. Sometimes the killing was done in ways that vicious as first tortured, burned and even mutilation. Becomes an interesting thing because mutilation is a murder followed by shredding the victim's body up into multiple parts made with the aim to destroy evidence. Not only that, the issue of sanctions against the perpetrators of criminal acts of mutilation murders under construction in the Indonesian criminal law there is no definite rules. Article which is often used as a legal basis for the criminal murder mutilation is Article 338, 340 and 351 Criminal Code with a maximum penalty of death, sometimes as an alternative to imprisonment. While the Islamic criminal law sanctions for deliberate murder is Qisas. And the impact of the crime of murder mutilation is very large, in addition to sadistic perpetrator in treating the bodies of the victims, but also causes damages to the family of the slain of the two sides, they lose those who earn a living, and his heart was sad at the loss of loved ones.
\end{abstract}

Keywords: Murder, Mutilation, Punishment, Islamic Criminal Law, National Criminal Law.

\begin{abstract}
Abstrak :
Kejahatan merupakan persoalan yang dihadapi manusia dari waktu ke waktu. Berbicara mengenai kejahatan khususnya pembunuhan, terus mengalami perkembangan yang diiringi dengan gaya dan bentuk yang sangat beragam, dari cara yang paling sederhana sampai yang sangat canggih. Terkadang pembunuhan itu dilakukan dengan cara-cara yang keji seperti disiksa lebih dahulu, dibakar dan bahkan mutilasi. Menjadi suatu hal yang menarik karena mutilasi adalah pembunuhan yang diikuti dengan memotong-motong tubuh korban hingga menjadi beberapa bagian yang dilakukan dengan tujuan untuk menghilangkan bukti. Tidak hanya itu, masalah sanksi terhadap pelaku tindak pidana pembunuhan secara mutilasi ini dalam konstruksi hukum pidana di Indonesia belum ada aturan yang pasti. Pasal yang sering dijadikan sebagai dasar hukum pelaku tindak pidana pembunuhan secara mutilasi adalah Pasal 338, 340 dan 351 KUHP dengan sanksi maksimal hukuman mati, yang terkadang hanya merupakan alternatif dari hukuman penjara. Sedangkan dalam hukum pidana Islam sanksi yang dijatuhkan bagi pembunuhan sengaja adalah Qishash. Dan dampak dari tindak pidana pembunuhan secara mutilasi ini sangat besar, disamping sadisnya pelaku dalam memperlakukan mayat korban, tapi juga mengakibatkan kerugian bagi keluarga si terbunuh dari dua sisi, yaitu mereka kehilangan orang yang mencari nafkah dan hatinya sedih karena kehilangan orang yang dicintainya.
\end{abstract}

Kata Kunci: Pembunuhan, Mutilasi, Pemidanaan, Hukum Pidana Islam, Hukum Pidana Nasional. 


\section{PENDAHULUAN}

\section{Latar Belakang}

Negara Republik Indonesia adalah negara hukum berdasarkan Pancasila dan Undang-Undang Dasar Negara Republik Indonesia (UUDNRI) Tahun 1945, yang memiliki tujuan mewujudkan tata kehidupan negara dan bangsa yang adil dan sejahtera, aman, tentram, tertib dan menjamin kedudukan hukum yang sama bagi warga masyarakat. Penegasan bahwa negara hukum adalah cita hukum (recht idée) Indonesia yang secara normatif diatur dalam Pasal 1 ayat (3) UUDNRI Tahun 1945 perubahan ketiga, yang menyebutkan bahwa:

"Negara Indonesia adalah Negara Hukum." Ketentuan pasal tesebut merupakan landasan konstitusional bahwa Negara Indonesia adalah negara yang berdasarkan atas hukum, hukum ditempatkan sebagai satusatunya aturan main dalam kehidupan bernegara dan bermasyarakat".

Istilah negara hukum dalam bahasa asing adalah rechtstaat dan the rule of law. Konsep rechtstaat bertumpu pada sistem hukum Kontinental yang disebut Civil Law, sedangkan konsep the rule of law bertumpu pada sistem hukum Anglo Saxon yang disebut Common Law.

Sistem hukum Anglo Saxon (Common Law) ialah suatu sistem hukum yang didasarkan pada yurisprudensi. Sumber hukum dalam sistem hukum ini ialah putusan hakim/pengadilan. Dalam sistem hukum ini peranan yang diberikan kepada seorang hakim sangat luas. Sedangkan sistem hukum yang dianut oleh negara-negara Eropa
Kontinental yang didasarkan atas hukum Romawi disebut sebagai sistem Civil Law, yang memiliki karakteristik antara lain yaitu adanya kodifikasi, hakim tidak terikat kepada presiden, dan sistem peradilan bersifat inkuisitorial atau bahwa hakim mempunyai peranan besar dalam mengarahkan dan memutuskan perkara, hakim aktif dalam menemukan fakta dan cermat dalam menilai alat bukti.

Dalam pemakaian istilah rechtstaat yang kemungkinan besar dipengaruhi oleh konsep hukum Kolonial Belanda, dimana Negara Indonesia adalah termasuk dalam wilayah sistem hukum Eropa Kontinental. Konsepsi negara hukum di Indonesia dapat diketahui dari perumusan mengenai tujuan bernegara sebagaimana dirumuskan dalam Pembukaan Undang-Undang Dasar Negara Republik Indonesia Tahun 1945 adalah, antara lain, untuk melindungi segenap bangsa dan tumpah darah Indonesia serta memajukan kesejahteraan umum.

Hukum adalah tata aturan (order) sebagai suatu sistem aturan-aturan (rules) tentang perilaku manusia. Dengan demikian hukum tidak menunjuk pada satu aturan tunggal (rule), tetapi seperangkat aturan (rules) yang memiliki suatu kesatuan sehingga dapat dipahami sebagai suatu sistem. Konsekuensinya, adalah tidak mungkin memahami hukum jika hanya memperhatikan satu aturan saja. ${ }^{1}$

${ }^{1}$ Jimly Asshiddiqie dan M. Ali Safa'at. Teori Hans Kelsen Tentang Hukum. Jakarta : Konstitusi Press, 2006, hlm 13 
Seperti kita ketahui bahwa negara Indonesia adalah negara yang terdiri dari berbagai macam suku, agama dan adat istiadat yang beraneka ragam dari sabang sampai merauke yang memiliki istilah Bhinneka Tunggal Ika. Adat istiadat tersebut sangat berbeda satu sama lainnya, sejak negara ini memproklamirkan kemerdekaannya maka, Indonesia terbentuk menjadi negara kesatuan dengan memiliki satu sistem hukum yang berlaku secara Nasional. Yang mana sistem hukum itu merupakan salah satu alat pengintegrasi bangsa ini.

Sistem hukum Indonesia sampai saat ini masih berlaku adalah sistem hukum yang masih berkiblat kepada negara Belanda yaitu sistem hukum Eropa Continental atau sistem hukum Civil Law. Bukti adanya sistem hukum ini adalah Kitab UndangUndang Hukum Pidana (KUHP) dan Kitab Undang-Undang Hukum Perdata (KUHPer) yang sampai saat ini dianggap masih tetap berlaku, sebagaimana dimaksud dalam Pembukaan Undang-Undang Dasar 1945, Pasal 1 Aturan Peralihan yang berbunyi: "segala peraturan perundangundangan yang ada masih tetap berlaku selama belum diadakan yang baru menurut Undang-Undang Dasar ini". 2

Selanjutnya, dalam aspek sejarah, kehadiran Agama Islam dapat dikatakan sebagai awal dari gerakan kemerdekaan yang dipelopori oleh Nabi Muhammad SAW. Hal itu dapat dibuktikan dengan dalil-dalil AlQur'an yang diturunkan kepada Beliau dan dengan sabda-sabda

2 Perubahan Ke-Empat, Undang-Undang Dasar Negara Republik Indonesia Tahun 1945.
Rasulullah sendiri, yang sering disebut sebagai Hadist. Adapun dalam praktek beragama, Agama Islam memiliki aturan main yang dikenal dengan istilah Hukum Islam, dimana aturan tersebut berdasarkan sumber Al-Qur'an dan Al-Hadist.

Berkaitan dengan hal kejahatan pembunuhan, dalam kitab suci agama samawi disebutkan bahwa peristiwa pembunuhan yang pertama kali terjadi di muka bumi adalah ketika Qabil membunuh saudaranya yang bernama Habil. Setelah peristiwa tersebut, pembunuhan sebagai tindak pidana kejahatan yang menghilangkan nyawa orang lain banyak terjadi yang dilatarbelakangi oleh beberapa motivasi pelakunya atas perbuatannya terhadap korban dengan waktu, tempat, cara dan unsur yang berbeda.

Seiring dengan berjalannya waktu dan kemajuan jaman, tindak pidana kejahatan pembunuhan dapat terjadi dalam berbagai bentuk. Salah satunya adalah pembunuhan yang disertai oleh tindakan menganiaya dengan memotong-motong jasad korbannya. Tindakan ini dikenal dengan istilah mutilasi.

\section{Masalah Mutilasi}

Peristiwa pembunuhan terus mengalami perkembangan yang diiringi dengan bentuk yang sangat beragam, dari cara yang paling sederhana sampai yang sangat canggih. Terkadang pembunuhan itu dilakukan dengan cara-cara yang keji seperti di aniaya lebih dahulu, di bakar dan bahkan di potong-potong, yang sering disebut dengan mutilasi. Menjadi suatu hal yang menarik 
karena mutilasi adalah pembunuhan yang diikuti dengan memotongmotong tubuh korban hingga menjadi beberapa bagian yang dilakukan dengan tujuan untuk menghilangkan jejak pembuktian.

Penerapan sanksi hukuman yang sering dijadikan sebagai dasar Hukum Pidana Nasional pelaku tindak pidana pembunuhan secara mutilasi adalah Pasal 340 KUHP dengan sanksi maksimal hukuman mati, yang terkadang hanya merupakan alternatif dari hukuman penjara. Sedangkan dalam Hukum (Pidana) Islam sanksi yang dijatuhkan bagi pembunuhan sengaja adalah Qishash.

Oleh karena itu, penulis dalam tulisan ini akan menganalisa bagaimanakah pandangan Hukum Pidana Nasional di Indonesia dan Hukum (Pidana) Islam tentang pelaku tindakan pemotongan tubuh korban secara mutilasi dan dapatkah mutilasi disebut sebagai kejahatan pembunuhan atau penganiayaan, serta sanksi hukum apakah yang dapat diterapkan pada pelaku tindak pidana mutilasi dalam konsep pemidanaan baik berdasarkan Hukum Pidana Nasional di Indonesia maupun secara Hukum (Pidana) Islam.

\section{TINDAK PIDANA MUTILASI}

\section{Menurut Hukum Pidana Nasional Indonesia}

Terlebih dahulu akan dijelaskan mengenai pengertian pembunuhan secara umum, istilah pembunuhan biasanya disepadankan dengan istilah homicide dalam bahasa inggris. Dalam Webster's New World Dictionary of The
American Language diuraikan bahwa istilah homicide berasal dari dua kata, yakni kata homo yang berarti a man atau manusia dan caedere yang berarti to cut (memotong) atau to kill (membunuh). Sehingga bila kedua kata tersebut digabungkan akan menjadi homidice yang artinya adalah setiap perbuatan membunuh seseorang oleh orang lain. ${ }^{3}$

Di Indonesia, mutilasi dikategorikan dalam jenis tindak pidana kejahatan pembunuhan, namun tidak semua kejahatan pembunuhan diiringi dengan perbuatan mutilasi. Para pelaku melakukan modus operandi kejahatan pembunuhan dengan mutilasi ini dengan tujuan untuk mengelabuhi para petugas kepolisian agar identitas korban sulit untuk dilacak dan ditemukan serta menghilangkan jejak dari para korban tindakan kriminal si pelaku, seperti memotong bagian tubuh korban menjadi beberapa bagian, yang kemudian bagian-bagian tubuh tersebut dibuang secara terpisah. Hal inilah yang menjadikan setiap kasus kejahatan mutilasi selalu menarik perhatian media massa baik cetak maupun elektronik dan seringkali disertai dengan judul yang cenderung menarik pembaca dan pendengarnya.

Kejahatan mutilasi adalah jenis kejahatan yang tergolong sadis, dimana pelaku kejahatan tersebut tidak hanya membunuh atau menghilangkan nyawa orang lain melainkan juga dengan memotongmotong setiap bagian tubuh korbannya. Motivasi memang merupakan pendorong utama

${ }^{3}$ Eko Hariyanto. Memahami Pembunuhan. Jakarta : Kompas, 2014, hlm 1. 
seseorang melakukan kejahatan. Kalangan ahli tidak seragam dalam melihat perilaku mutilasi, karena motif, bentuk dan karakter perilaku pelakunya sangat beragam. Penulis melihat dari beberapa kasus mutilasi yang terjadi, ada beberapa hal yang melatarbelakanginya tindak pidana kejahatan tersebut, antara lain, motifnya kebanyakan terkait dengan perilaku seksual, adanya dendam, kasusnya relative sulit di ungkap bahkan sebagian besar tidak berhasil diungkap oleh polisi disebabkan keinginan pelaku untuk menghilangkan jejak.

Berdasarkan teori ilmu kriminologi, pelaku kejahatan mutilasi ini cenderung termasuk adalah orangorang yang memiliki kelainan suara hati dan cenderung mengalami gangguan jiwa atau prilaku psikopat. Menurut Teori Psikologi Kriminal, Personality Characteristics (sifat-sifat kepribadian), dinyatakan bahwa ada empat alur penelitin psikologis yang berbeda telah menguji hubungan antara kepribadian dengan kejahatan. Pertama, melihat pada perbedaanperbedaan antara struktur kepribadian dari penjahat dan bukan penjahat. Kedua, memprediksi tingkah laku. Ketiga, menguji tingkatan di mana dinamika-dinamika kepribadian normal beroperasi dalam diri penjahat. Dan Keempat, mencoba menghitung perbedaan-perbedaan individual antara tipe-tipe dan kelompok - kelompok pelaku kejahatan. ${ }^{4}$
Berdasarkan teori ini kemungkinan untuk dilakukannya sebuah kejahatan mutilasi yaitu dapat terjadi karena sifat-sifat kepribadian dari diri seseorang (Personality Characteristics).

Tindak Pidana Pembunuhan memang sudah lama di kenal oleh Hukum Nasional kita melalui Kitab Undangundang Hukum Pidana (KUHP). Pengaturan dalam Bab XIX Buku II KUHP menggolongkan beberapa perbuatan yang dapat dikategorikan sebagai Kejahatan terhadap Nyawa. Jenis Pembunuhan yang di atur dalam bab ini meliputi Pembunuhan dengan Sengaja (Pasal 338), Pembunuhan dengan rencana (Pasal 340), Pembunuhan anak setelah lahir oleh Ibu (Pasal 341-342), dan Pengguguran kandungan (pasal 346-349). Sama sekali tidak terdapat satu pasal pun yang mengatur tentang tindak pidana pembunuhan yang diikuti pemotongan tubuh korban. Keadaan ini tentu saja dapat menimbulkan masalah hukum tentang kepastian hukum dan keadilan bagi masyarakat.

Untuk dapat disebut sebagai tindak pidana suatu tindakan haruslah memenuhi beberapa persyaratan, yaitu tindakan tersebut telah tercantum dan diatur didalam ketentuan hukum sebagai tindakan yang terlarang baik secara formil atau materil yang dikenal dengan asas legalitas. Kiranya terdapat persamaan pandangan di antara para ahli hukum pidana bahwa pengertian asas legalitas adalah; "tiada perbuatan dapat dipidana kecuali atas dasar kekuatan ketentuan pidana menurut undang-

${ }^{4}$ Topo Santoso dan Eva Achjani Zulfa. Kriminologi. Jakarta: Rajawali Pers, 2014, hlm 49. 
undang yang sudah ada terlebih dahulu. $^{5}$

Ketentuan tersebut diatas sebagaimana termaktub dalam Pasal 1 ayat (1) KUHP adalah definisi baku dari asas legalitas, yang berbunyi "tiada suatu perbuatan boleh dihukum, melainkan atas ketentuan pidana dalam undang-undang yang ada terdahulu dari pada perbuatan itu". Dari definisi tersebut, yang penting untuk diulas selanjutnya adalah makna "perbuatan yang dapat dipidana dan ketentuan pidana menurut undang-undang".

Tindak pidana kejahatan pembunuhan pertama-tama diancam hukuman dalam Pasal 338 KUHP yang bunyinya : Barangsiapa dengan sengaja menghilangkan jiwa orang lain, dihukum karena pembunuhan biasa, dengan hukuman penjara selama-lamanya lima belas tahun".

Teknis pembunuhan ini dinamakan delik material, dimana kejahatan baru dianggap selesai, apabila akibatnya telah terjadi dan tidak dirumuskan cara bagaimana pembunuhan itu dilakukan. Maksud dari pembunuhan biasa (doodslag), dimana diperlukan suatu perbuatan yang mengakibatkan kematian orang lain, sedangkan kematian itu dilakukan dengan niat disengaja atau dengan maksud adanya niat dari pelaku.

Apabila kematian korban tidak dengan maksud atau tidak dengan sengaja, maka tidak masuk dalam pasal ini, mungkin masuk Pasal 359 KUHP (karena salahnya

5 Eddy O.S. Hiariej, Asas Legalitas dan Penemuan Hukum, Jakarta : Erlangga, 2009, hlm 19. menyebabkan matinya orang lain), sebagai delik culpa, dimana perbuatan kurang berhati-hati diancam hukuman, atau mungkin dapat dikenakan Pasal 351 ayat (3) tentang penganiayaan biasa yang berakibat matinya orang lain, atau Pasal 353 ayat (3) tentang penganiayaan biasa dengan direncanakan lebih dahulu berakibat matinya orang lain), atau Pasal 354 ayat (2) tentang penganiayaan berat yang mengakibatkan mati), atau pasal 355 ayat (2) tentang penganiayaan berat dengan direncanakan lebih dahulu yang mengakibatkan matinya orang lain.

Sedangkan apabila kematian korban dengan maksud atau dengan sengaja akan membunuh dan pelaku dengan tenang masih dapat memikirkan dengan cara bagaimana ia akan melakukan pembunuhan itu, pelaku dapat dikenakan Pasal 340 KUHP yang bunyinya : "barangsiapa dengan sengaja dan dengan direncanakan lebih dahulu menghilangkan jiwa orang lain, dihukum karena pembunuhan direncanakan (moord), dengan hukuman mati atau penjara seumur hidup atau penjara sementara selama-lamanya dua puluh tahun". 6

Pengertian kata "dengan direncanakan lebih dahulu" menurut M.v.T pembentukan Pasal 340 KUHP diutarakan, antara lain: dengan rencana lebih dahulu diperlukan saat pemikiran dengan tenang dan berpikir dengan tenang. Untuk itu sudah cukup jika si pelaku berpikir sebentar saja sebelum atau pada waktu ia akan

${ }^{6}$ R. Soesilo, Kitab Undang-Undang Hukum Pidana (KUHP) Serta Komentar-Komentarnya Lengkap Pasal Demi Pasal. Bogor: Politeia, 1991, hlm 241. 
melakukan kejahatan sehingga ia menyadari apa yang dilakukannya". ${ }^{7}$

Didalam ketentuan Kitab UndangUndang Hukum Pidana (KUHP) sebagaimana tersirat dalam pasal tersebut diatas sangat jelas sekali bahwa para pelaku yang melakukan pembunuhan dalam hal ini adalah pembunuhan berencana, maka akan dipidana dengan hukuman mati atau pidana penjara seumur hidup.

Sebagai fenomena dalam masyarakat, kejahatan disertai dengan kekerasan merupakan kejahatan tradisional yang telah ada sejak dahulu, namun bentuknya sekarang telah mengalami modifikasi. Fenomena yang sama juga terjadi di Indonesia, kejahatan kekerasan menjadi perhatian pemerintah dan masyarakat karena terjadi tidak hanya di kota-kota besar, tetapi juga di beberapa daerah. Di Propinsi Jawa Barat misalnya, pada bulan Agustus lalu, dalam kasus dan peristiwa yang berbeda masyarakat Depok dikejutkan dengan penemuan mayat dalam plastik di sebuah selokan. Mayat tanpa identitas ini di temukan dalam keadaan mengerikan, dari seluruh bukti yang ditemukan ternyata korban telah di potongpotong. Kisah Ryan 'si jagal manusia' dari Jombang mengaku telah melakukan pembunuhan diikuti pemotongan terhadap salah satu korban terakhirnya. Very Idham Henyansyah alias Ryan (38), telah menyodomi, membunuh dan memutilasi sebagian korban yang berjumlah 10 (sepuluh) orang dengan mengubur potongan tubuh korbannya dibelakang pekarangan rumah

${ }^{7}$ Leden Marpaung, Tindak Pidana Terhadap Nyawa dan Tubuh., Jakarta : Sinar Grafika, 2005, hlm 31 orangtua Ryan di Desa Jatiwates, Kecamatan Tembelang, Jombang, Jawa Timur. Alasan Ryan membunuh dan memutilasi adalah karena cemburu, dendam dan ingin menguasai harta milik korban dan ia juga adalah seorang homoseksual. ${ }^{8}$

Dari uraian tersebut diatas, Si pelaku seolah-olah menganggap tindakan pembunuhan yang dilakukannya itu belumlah cukup sehingga harus diikuti dengan tindakan mutilasi pada korbannya.

Dalam Oxford Dictionary, memberikan definisi mutilasi sebagai "damage sb's body severely, esp by cutting or tearing off part of it."

Apabila di kaji secara mendalam, tindak mutilasi ini terbatas pada korban yang berwujud manusia alamiah baik perseorangan maupun kelompok dan bukanlah binatang. Tindakan ini dapat dilakukan oleh pelaku terhadap korban pada waktu masih bernyawa ataupun pada mayat korban. Tindakan pemotongan manusia secara hidup-hidup ataupun mayat jelas merupakan tindakan yang sangat di cela oleh masyarakat dan dianggap sebagai tindakan yang sangat jahat dan sadis. Oleh karena itu, menurut penulis tindak pidana kejahatan mutilasi sangatlah tepat jika di golongkan ke dalam kejahatan pembunuhan secara berencana.

\section{Menurut Hukum Pidana Islam}

Secara nyata manusia tidak mundur dari kejahatan, walaupun para pelaku

\footnotetext{
${ }^{8}$ Hermawan Aksan, Jejak Pembunuh Berantai, Jakarta : Grafidia, 2008, hlm 58.

${ }^{9}$ Dictionary, Oxford Learner's Pocket Dictionary. New York : Oxford University Press, 2004, hlm 283.
} 
menyadari bahwa tindakan tersebut akan dihukum. Jadi sebenarnya sangatlah sulit untuk menghentikan suatu kejahatan, termasuk pula dengan kejahatan pembunuhan. Salah satu varian dari kejahatan kekerasan adalah kejahatan pembunuhan. Unsur tindakan yang disengaja dan menyebabkan kematian terlihat jelas terutama pada kejahatan pembunuhan dengan cara mutilasi. Namun setidaknya kejahatan seperti mutilasi ini dapat diminimalisir dengan cara pencegahan-pencegahan tertentu.

Kejahatan mutilasi atas korban tampaknya merupakan hal yang menarik jika ditilik dari aspek-aspek pembunuhan seperti diuraikan di atas karena seringkali kejahatan mutilasi disamakan begitu saja dengan kejahatan pembunuhan. Selain mengingat kejahatan tersebut beragam jenisnya, maka diperlukan data akurat melalui sebuah penelitian kriminologi, viktimologi dan hukum pidana tentang pelaku kekerasan. Berdasarkan studi tentang kejahatan kekerasan tersebut, kejahatan mutilasi cenderung dijadikan satu dengan kategori trend kejahatan pembunuhan. ${ }^{10}$

Dalam hukum Islam, kejahatan (jarimah/jinayat) didefinisikan sebagai larangan-larangan hukum yang diberikan Allah, yang pelanggarnya membawa hukuman yang ditentukanNya. Larangan hukum berarti melakukan perbuatan yang dilarang atau tidak melakukan suatu perbuatan yang tidak diperintahkan. Dengan

${ }^{10}$ Imran, Mohammad Fadil. Mutilasi Dalam Perspektif Kriminologi : Tinjauan Teoritis Lima Kasus mutilasi di Jakarta. Jakarta : Yayasan Pustaka Obor Indonesia, 2015. demikian, suatu kejahatan adalah perbuatan yang hanya dilarang oleh syariat. Dengan kata lain, melakukan (commission) atau tidak melakukan (ommission) suatu perbuatan yang membawa kepada hukuman yang ditentukan oleh syariat adalah kejahatan. ${ }^{11}$

Para ahli hukum Islam membagi kejahatan dalam tiga klasifikasi, yaitu hudud, qishash, dan ta'zir. Kejahatan hudud adalah kejahatan yang paling serius dan berat dalam hukum pidana Islam. Ia adalah kejahatan terhadap kepentingan publik. Tetapi ini tidak berarti bahwa kejahatan hudud tidak mempengaruhi kepentingan pribadi sama sekali, namun terutama sekali berkaitan dengan apa yang disebut hak Allah. Dengan demikian, kejahatan dalam kategori ini dapat didefinisikan sebagai kejahatan yang diancam dengan hukuman hadd, yaitu hukuman yang ditentukan sebagai hak Allah. Jenis kejahatan yang tergolong kejahatan hudud ini adalah riddah (murtad), al-baghy (pemberontakan), zina, qadzab (tuduhan palsu zina), sariqah (pencurian), hirabah (perampokan), dan shurb al-khamr (meminum khamar).

Kategori berikutnya adalah qishash. Ia jatuh pada posisi ditengah antara kejahatan hudud dan ta'zir dalam hal beratnya. Kejahatan-kejahatan dalam kategori ini kurang serius dibanding yang pertama (hudud), namun lebih berat daripada yang berikutnya (ta'zir). Sasaran dari kejahatan ini adalah integritas tubuh manusia, sengaja atau tidak disengaja. Ia terdiri

11 Topo Santoso. Membumikan Hukum Pidana Islam: Penegakan Syariat dalam Wacana dan Agenda. Jakarta: Gema Insani Press, 2003, hlm 20. 
dari apa yang dikenal dalam hukum pidana modern sebagai kejahatan terhadap manusia atau crimes against persons. Jadi, pembunuhan dengan sengaja, pembunuhan menyerupai sengaja, pembunuhan karena kealpaan, penganiayaan, menimbulkan luka/sakit karena kelalaian, masuk dalam kategori tindak pidana qishash ini.

Kategori terakhir adalah kejahatan ta'zir. Landasan dan penetuan hukumannya didasarkan pada 'ijma (konsensus) berkaitan dengan hak negara muslim untuk melakukan kriminalisasi dan menghukum semua perbuatan yang tidak pantas, yang menyebabkan kerugian/kerusakan fisik, sosial, politik, finansial, atau moral bagi individu atau masyarakat secara keseluruhan. ${ }^{12}$

Pembunuhan adalah suatu aktivitas yang dilakukan oleh seseorang dan/atau beberapa orang yang mengakibatkan seseorang dan/atau beberapa orang meninggal dunia. Apabila diperhatikan dari sipat perbuatan seseorang dan/atau beberapa orang dalam melakukan pembunuhan, maka dapat dikelompokkan menjadi : disengaja (amd), tidak disengaja (khata), dan semi disengaja (syibhu al-amd). ${ }^{13}$

a. Pembunuhan Disengaja Pembunuhan disengaja (amd) adalah perbuatan yang dilakukan oleh seseorang dengan tujuan untuk membunuh orang lain dengan menggunakan alat yang dipandang layak untuk dibunuh. b. Pembunuhan Tidak Disengaja Pembunuhan tidak disengaja (khata) adalah perbuatan yang dilakukan oleh seseorang dengan tidak ada unsur kesengajaan yang mengakibatkan orang lain meninggal dunia.

c. Pembunuhan Semi Sengaja Pembunuhan semi sengaja (syibhu al-amd) adalah perbuatan yang sengaja dilakukan oleh seseorang kepada orang lain dengan tujuan mendidik.

Dari ketiga jenis tindak pidana pembunuhan tersebut diatas, sanksi hukuman qishash hanya berlaku pada pembunuhan jenis pertama, yaitu jenis pembunuhan disengaja. Adapun kedua jenis pembunuhan lainnya, sanksi hukumnya berupa diyat. Dalil yang mewajibkan hukuman secara qishash ini tidak hanya berdasarkan Al-Quran, tetapi juga berdasarkan Hadist Nabi Muhammad SAW.

Dasar hukum sanksi pembunuhan di dalam Al-Quran, antara lain adalah: ${ }^{14}$

a. Surah Al-Baqarah Ayat 178 - 179, yang artinya berbunyi : "Wahai orang-orang yang beriman ! Diwajibkan atas kamu (melaksanakan) Qishash berkenaan dengan orang-orang yang dibunuh. Orang merdeka dengan orang merdeka, hamba sahaya dengan hamba sahaya, perempuan dengan perempuan. Tetapi siapa yang memperoleh maaf dari saudaranya, hendaklah dia mengikutinya dengan baik, dan membayar diat (tebusan)

${ }^{12}$ Ibid., hlm 23.

13 Zainuddin Ali. Hukum Pidana Islam. Jakarta :

${ }^{14}$ Ahmad Hatta, Tafsir Qur'an Per Kata; Dilengkapi Dengan Asbabun Nuzul \& Terjemah, Jakarta: Sinar Grafika, 2012, hlm 24. 
kepadanya dengan baik (pula). Yang demikian itu adalah keringanan dan rahmat dari Tuhanmu. Siapa yang melampaui batas setelah itu, maka ia akan mendapat azab yang sangat pedih."

b. Surah Al-Baqarah Ayat 179, yang artinya berbunyi : "Dan dalam qishash itu ada (jaminan) kelangsungan kehidupan bagimu, wahai orang-orang yang berakal, agar kamu bertakwa."

c. Surah An-Nisa Ayat 92, yang artinya berbunyi : "Dan bagi seorang yang beriman, tidak patut membunuh seorang yang beriman (yang lain), kecuali karena tersalah (tidak sengaja). Siapa yang membunuh seorang yang beriman karena tersalah (hendaklah) dia memerdekakan seorang hamba sahaya yang beriman serta (membayar) tebusan yang diserahkan kepada keluarganya (si terbunuh itu), kecuali jika mereka (keluarga terbunuh) membebaskan pembayaran. Jika dia (si terbunuh) dari kaum yang memusuhimu, padahal dia orang beriman, maka (hendaklah si pembunuh) memerdekakan hamba sahaya yang beriman. Dan jika dia (si terbunuh) dari kaum (kafir) yang ada perjanjian (damai) antara mereka dengan kamu, maka (hendaklah si pembunuh) membayar tebusan yang diserahkan kepada keluarganya (si terbunuh) serta memerdekakan hamba sahaya yang beriman. Siapa yang tidak mendapatkan (hamba sahaya), maka hendaklah dia (si pembunuh) berpuasa dua bulan berturut-turut sebagai taubat kepada Allah. Dan Allah Maha Mengetahui, Maha Bijaksana."

d. Surah An-Nisa Ayat 93, yang artinya berbunyi : "Dan siapa yang membunuh seorang yang beriman dengan sengaja, maka balasannya ialah neraka jahannam, dia kekal didalamnya. Allah murka kepadanya, dan melaknatnya serta menyediakan azab yang besar baginya."

e. Surah A1-Maidah Ayat 32, yang artinya berbunyi : "Oleh karena itu Kami tetapkan (suatu hukum) bagi Bani Israel, bahwa barang siapa membunuh seseorang, bukan karena orang itu membunuh orang lain, atau bukan karena berbuat kerusakan di bumi, maka seakan-akan dia telah membunuh semua manusia. Siapa yang memelihara kehidupan seorang manusia, maka seakan-akan dia telah memelihara kehidupan semua manusia. Sesungguhnya Rasul Kami telah datang kepada mereka dengan (membawa) keterangan-keterangan yang jelas. Tetapi kemudian banyak di antara mereka setelah itu melampaui batas di bumi."

f. Surah An-Maidah Ayat 45, yang artinya berbunyi : "Kami telah menetapkan bagi mereka didalamnya (Taurat) bahwa nyawa (dibalas) dengan nyawa, mata dengan matal, hidung dengan hidung, telinga dengan telinga, gigi dengan gigi, dan luka-luka (pun) ada qishashnya (balasan yang sama), maka itu (menjadi) penebus dosa baginya. Barangsiapa tidak memutuskan perkara menurut apa yang 
diturunkan Allah, maka mereka itulah orang-orang zalim."

Dasar hukum sanksi pembunuhan di dalam Al-Hadist, antara lain adalah $:^{15}$

a. Diriwayatkan dari Abdullah bin Mas'ud r.a, ia berkata, Rasulullah SAW pernah bersabda: "Sesuatu yang pertama kali diadili di antara manusia pada hari kiamat adalah masalah darah (yakni tindak pidana dengan menumpahkan darah atau pembunuhan)." (HR. Bukhari No 6533)

b. Diriwayatkan dari Anas r.a, bahwasannya saudara perempuan Rubayyi, yaitu Ummu Haritsah, telah melukai seseorang, lalu mereka minta pengadilan kepada Rasullah SAW, maka Rasullah bersabda : "Lakukan Qishash! Lakukan Qishash!". Kata Ummu Rubayyi, " Ya Rasulullah! Apakah dia akan di Qishash? Demi Allah! Dia tidak boleh diqishash!. Lalu Nabi bersabda : "Subhanallah! Hai Ummu Rubayy, qishash adalah ketetapan Allah." Kata Ummu Rubayyi, "Jangan Demi Allah! Dia tidak boleh diqishash selamanya." Kata Anas : Ummu Rubayyi selalu mengatakan begitu sehingga keluarga korban rela menerima uang denda. Maka Rasulullah SAW bersabda : "Sungguh di antara hamba-hamba Allah ada orang yang apabila bersumpah pasti dia akan melaksanakannya." (HR. Bukhari No 2703)

15 Imam Al-Mundziri. Ringkasan Hadis Shahih Muslim. Jakarta : Pustaka Amani, 1994, hlm 562 c. Diriwayatkan dari Abu Hurairah beliau bekata, Rasulullah SAW bersabda : "Barangsiapa mendapati keluarganya dibunuh maka dia berhak memilih dua perkara, antara diyat dan qishash." (HR. Bukhari No 6880)

Selanjutnya diartikan oleh para ulama sebagai suatu perbuatan manusia yang menyebabkan hilangnya nyawa. Mazhab Maliki hanya membagi pembunuhan menjadi dua macam, yakni pembunuhan secara sengaja dan pembunuhan tak sengaja. Sedangkan para ulama Hanafiyah, Syafiiyah, dan Hambali membagi pembunuhan menjadi tiga macam, yaitu pembunuhan sengaja (qatl al-'amd), yakni suatu perbuatan penganiayaan terhadap seseorang dengan maksud untuk menghilangkan nyawanya, pembunuhan semi sengaja (qatl syibh al-'amd), yakni perbuatan penganiayaan terhadap seseorang tidak dengan maksud untuk membunuhnya, tetapi mengakibatkan kematian, dan pembunuhan karena kesalahan (qatl al-khata'), yakni pembunuhan yang disebabkan salah dalam perbuatan, salah dalam maksud dan kelalaian.

Adapun unsur dari pembunuhan sengaja yaitu, korban adalah orang yang hidup, perbuatan si pelaku mengakibatkan kematian korban, dan ada niat bagi si pelaku untuk menghilangkan nyawa korban. Sedangkan unsur pembunuhan semi sengaja yaitu, pelaku melakukan perbuatan yang mengakibatkan kematian, ada maksud penganiayaan atau permusuhan (jadi bukan niat 
membunuh) dan ada hubungan sebab akibat antara perbuatan pelaku dengan kematian korban. Selanjutnya, unsur pembunuhan karena kesalahan yaitu, adanya perbuatan yang menyebabkan kematian, terjadinya perbuatan itu karena kesalahan, dan adanya sebab akibat antara perbuatan kesalahan dan kematian korban.

Sanksi bagi pembunuhan sengaja ada beberapa jenis, yaitu hukuman pokok, hukuman pengganti, dan hukuman tambahan. Hukuman pokok pembunuhan adalah qishash. Bila dimaafkan oleh keluarga korban, maka hukuman penggantinya adalah diyat. Jika sanksi qishash atau diyat dimaafkan, maka hukuman penggantinya adalah ta'zir. Hukuman tambahan bagi tindak pidana ini adalah terhalangnya hak atas warisan dan wasiat.

Sementara itu, hukuman pokok pada pembunuhan semi sengaja adalah diyat dan kaffarat, sedangkan hukuman penggantinya adalah puasa dan ta'zir, dan hukuman tambahannya adalah terhalang menerima warisan dan wasiat.

Selanjutnya, sanksi pokok pembunuhan karena tersalah adalah diyat dan kaffarat. Hukuman penggantinya adalah puasa dan ta'zir, dan hukuman tambahannya adalah hilangnya hak waris dan hak mendapat wasiat. ${ }^{16}$

Adapun dari sumber hukum Al-Quran dan Al-Hadist tersebut diatas, para ulama dari berbagai mazhabnya dari dahulu sampai sekarang telah melakukan kesepakatan (ijma), bahwa

${ }^{16}$ Topo Santoso. Op.Cit., hlm 36. qishash termasuk perintah agama yang disyariatkan. Dengan demikian upaya implementasi hukuman qishash di Indonesia telah mendapat legitimasi sangat kuat dari agama. ${ }^{17}$

\section{Teori Harmonisasi Hukum}

Untuk mengukur sejauhmana urgensi hukuman qishash ini dapat diterapkan di Indonesia dan sejauhmana efektivitas hukuman pidana yang bersumber dari KUHP, maka salah satu cara adalah melihat fakta-fakta kejahatan pembunuhan dan data-data vonis kasus pembunuhan di Indonesia. Dalam pelaksanaan penerapan hukum terhadap pelaku tindak pidana mutilasi, dimana pengaturannya berdasarkan hukum positif yang bersumber pada dua sistem hukum yang berbeda yaitu Sistem Hukum Pidana Nasional yang bersumber pada Kitab UndangUndang Hukum Pidana (KUHP) dan Sistem Hukum Pidana Islam yang bersumber pada Al-Qur'an dan AlHadist. Sehingga tidak tertutup kemungkinan adanya pertentangan kaidah-kaidah dan konsep-konsep. Maka teori harmonisasi hukum digunakan untuk menselaraskan atau menserasikan perbedaan dan pertentangan tersebut.

Harmonisasi merupakan suatu proses menuju harmoni. Hal yang dilakukan adalah mengidentifikasi masalah, mendiagnosa bagian-bagian yang berbenturan yang memerlukan harmonisasi, sebab dan akibat dari benturan tersebut, pihak-pihak yang

17 Paisol Burlian. Implementasi Konsep Hukuman Qishash di Indonesia. Jakarta : Sinar Grafika, 2015, hlm 38 
terlibat, maksud dan tujuannya, dan dasar hukum masing - masing. ${ }^{18}$

Secara teoritis dikenal tiga model harmonisasi hukum, yaitu tinkering harmonization, following harmonization dan leading harmonization.

Tinkering harmonization merupakan harmonisasi hukum melalui optimalisasi penerapan hukum yang ada (existing law) dengan beberapa penyesuaian, dengan pertimbangan efisiensi.

Following harmonization, menunjuk pada harmonisasi hukum bidangbidang tertentu yang ditujukan untuk penyesuaian hukum yang ada (existing law) dengan perubahan-perubahan sosial.

Leading harmonization, menunjuk pada penerapan atau penggunaan hukum untuk melakukan perubahanperubahan sosial. ${ }^{19}$

Harmonisasi hukum diartikan sebagai upaya atau proses penyesuaian asas dan sistem hukum, agar terwujud kesederhanaan hukum, kepastian hukum dan keadilan. Harmonisasi hukum sebagai suatu proses dalam pembentukan peraturan perundangundangan, mengatasi hal-hal yang bertentangan dan kejanggalan di antara norma-norma hukum di dalam peraturan perundang-undangan, sehingga terbentuk peraturan perundang - undangan nasional yang harmonis, dalam arti selaras, serasi,

18 Martin Boodman. The Myth of Harmonization of Laws. The American Journal of Comparative Law, Vol. 39, No. 4 (Autumn, 1991), hlm 700

19 https://kgsc.wordpress.com/harmonization-oflaw/ seimbang, terintegrasi dan konsisten, serta taat asas. Langkah sistemik harmonisasi hukum nasional, bertumpu pada paradigma Pancasila dan UUD 1945 yang melahirkan sistem ketatanegaraan dengan dua asas fundamental, asas demokrasi dan asas negara hukum yang diidealkan mewujudkan sistem hukum nasional dengan tiga komponen, yaitu substansi hukum, struktur hukum beserta kelembagaannya, dan budaya hukum. Langkah sistemik tersebut di satu sisi dapat dijabarkan dalam harmonisasi peraturan perundangundangan dan di sisi lain diimplementasikan dalam rangka penegakan hukum.

Melalui harmonisasi hukum, akan terbentuk sistem hukum yang mengakomodir tuntutan akan kepastian hukum dan terwujudnya keadilan. Begitu pula dalam hal penegakan hukum, harmonisasi hukum akan dapat menghindari tumpang tindih bagi badan peradilan yang melakukan kekuasaan kehakiman, dengan badan-badan pemerintah yang diberi wewenang melakukan fungsi peradilan menurut peraturan perundang-undangan.

Setelah memahami teori atau konsep harmonisasi hukum, maka dapat dikemukakan proses atau langkahlangkah harmonisasi hukum pidana islam dan hukum pidana nasional, sebagai berikut:

1. Memahami karakteristik hukum yang ingin diharmonisasikan;

Ada dua sistem hukum yang berbeda, yaitu Hukum Islam dan Hukum Pidana Indonesia. Pada tahap ini kedua sistem hukum 
tersebut harus dipelajari karakteristiknya, antara lain dasar filosofisnya, aspek yuridis dan aspek sosiologisnya serta tujuannya.

2. Menemukan prinsip-prinsip hukum dari sistem hukum atau ketentuan hukum yang berbeda; Masing-masing sistem hukum tersebut memiliki prinsip-prinsip hukum tersendiri yang mungkin saja memiiki perbedaan atau pertentangan, dan persamaan. Semua prinsip-prinsip hukum digali dan dijabarkan dengan jelas, dan diperbandingkan satu dengan lainnya.

3. Menemukan titik taut objektif antara hukum yang ingin diharmonisasikan;

Hasil dari perbandingan prinsipprinsip hukum akan memberikan deskripsi tentang prinsip-prinsip yang bertentangan dan prinsipprinsip yang memiliki persamaan. Disinilah, akan dilihat titik taut objektif dari kedua sistem hukum yang berbeda terrebut, yang dapat menjadi pintu masuk dalam melakukan harmonisasi hukum.

4. Menentukan metode harmonisasi hukum.

Langkah terakhir adalah menetapkan metode harmonisasi hukum apa yang akan digunakan, apakah terbatas pada prinsipprinsip hukum utama saja, memilih hal-hal tertentu yang dianggap penting diharmonisasikan (parsial), atau diadopsi secara keseluruhan.

Keempat cara inilah yang akan digunakan sebagai instrument untuk mengharmonisasikan hukum islam dan hukum positif dalam penerapan dan penegakan hukum atas sanksi yang diberikan terhadap pelaku tindak pidana pembunuhan khususnya mutilasi.

\section{PENUTUP}

Hukum nasional Indonesia adalah hukum yang dibangun oleh warga negara Republik Indonesia sebagai pengganti hukum kolonial. Adapun dari segi KUHP, dalam konteks kejahatan terhadap nyawa manusia, persamaan hukuman qishash dengan pidana mati adalah bahwa hukuman qishash tercakup juga didalamnya pidana mati, seperti dalam kasus pembunuhan disengaja yang tidak dimaafkan oleh keluarga korban. Saat ini banyak orang beranggapan bahwa hukuman qishash lebih identik sebagai hukuman mati, padahal hukuman qishash mati hanya berlaku pada satu poin saja, yaitu: "pembunuhan disengaja yang tidak dimaafkan oleh keluarga korban", selebihnya dalam kasus pembunuhan lainnya, hukumannya adalah diyat.

Dengan demikan dapat disimpulkan bahwa hukuman bagi pembunuh khususnya mutilasi di Indonesia masih belum efektif. Sebagai relevansi masalah ini, Islam menawarkan konsep penting tentang masalah kejahatan terhadap nyawa manusia, dengan menyebutkan bahwa tindak pidana pembunuhan (al-qat) disebut dengan istilah kejahatan terhadap jiwa manusia (al-jinayah 'ala al-insaniyyah) dengan konsep Hukum Pidana Islam (Fiqh Jinayah). 


\section{DAFTAR PUSTAKA}

Aksan, Hermawan. Jejak Pembunuh Berantai. Jakarta: Grafidia, 2008.

Ali, Zainuddin. Hukum Pidana Islam. Jakarta: Sinar Grafika, 2012.

Al-Mundziri, Imam. Ringkasan Hadis Shahih Muslim. Jakarta : Pustaka Amani, 1994.

Asshiddiqie, Jimly dan Muchamad Ali Syafa'at. Teori Hans Kelsen Tentang Hukum. Jakarta: Konstitusi Press. 2006.

Boodman, Martin. The Myth of Harmonization of Laws. The American Journal of Comparative Law, Vol. 39, No. 4, Autumn, 1991.

Burlian, Paisol. Implementasi Konsep Hukuman Qishash di Indonesia. Jakarta : Sinar Grafika, 2015.

Dictionary. Oxford Learner's Pocket Dictionary. New York: Oxford University Press, 2004.

Hariyanto, Eko. Memahami Pembunuhan. Jakarta: Kompas Media Nusantara, 2014.

Hatta, Ahmad. Tafsir Qur'an Per Kata; Dilengkapi Dengan Asbabun Nuzul \& Terjemah. Jakarta: Maghfirah Pustaka, 2009.

Imran, Mohammad Fadil. Mutilasi Dalam Perspektif Kriminologi: Tinjauan Teoritis Lima Kasus mutilasi di Jakarta. Jakarta: Yayasan Pustaka Obor Indonesia, 2015.

Marpaung, Leden. Tindak Pidana Terhadap Nyawa dan Tubuh. Jakarta: Sinar Grafika, 2005.
O.S. Hiariej, Eddy. Asas Legalitas dan Penemuan Hukum. Jakarta: Erlangga, 2009.

Santoso, Topo. Membumikan Hukum Pidana Islam: Penegakan Syariat dalam Wacana dan Agenda. Jakarta: Gema Insani Press, 2003

Santoso, Topo dan Eva Achjani Zulfa. Kriminologi. Jakarta: Rajawali Pers, 2014.

Soesilo, R. Kitab Undang-Undang Hukum Pidana (KUHP) Serta KomentarKomentarnya Lengkap Pasal Demi Pasal. Bogor: Politeia, 1991.

Undang-Undang Dasar Negara Republik Indonesia Tahun 1945

https://kgsc.files.wordpress.com 